\title{
Fatalities in recreational boating and sub-aqua diving
}

\author{
Stephen E. Roberts ${ }^{1}$, Detlef Nielsen ${ }^{2}$, Bogdan Jaremin ${ }^{3}$ \\ ${ }^{1}$ College of Medicine, Swansea University, Swansea, United Kingdom \\ ${ }^{2}$ Messrs. Weselmann Asia Ltd, Hong Kong, China \\ ${ }^{3}$ Institute of Maritime and Tropical Medicine, Medical University of Gdansk, Gdansk, Poland
}

\begin{abstract}
Background and aim: To establish the causes and circumstances of fatalities in recreational boating and sub-aqua diving inland or around the United Kingdom during the years 2006 and 2007, to compare fatal accident rates according to the type of boat, to identify causal patterns, and to discuss preventative measures to reduce the fatalities.

Materials and methods: Examinations of marine accident files and reports from the Marine Accident Investigation Branch and other sources, including the Royal National Lifeboat Institution, Maritime and Coastguard Agency, Association of Inland Navigation Authorities and the British Sub-Aqua Diving Club.

Results: There were 102 fatalities in recreational boating and 28 in sub-aqua diving with corresponding fatal accident rates of 12.0 and 48.0 per million participants. In recreational boating, fatal accident rates were highest for motor and power boats (20.2), yachts (19.3) and canal boats (16.0). Most fatalities (64\%) occurred from April to September, with a peak during August. In recreational boating, $24 \%$ of fatalities were recorded as alcohol-related. These were most prevalent in canal boats, occurring largely during the autumn and winter months rather than during summer holidays, among people living on boats, often as a result of fires and falls overboard.

Conclusions: Causal patterns of the fatalities varied strongly according to the type of recreational boat and diving. Prevention of fatalities should include raising awareness of hazards, adequate training in diving, yachting and canoeing, etc., installation and maintenance of smoke alarms and fire extinguishers on residential boats, and increases in the use of personal flotation devices in recreational boating.
\end{abstract}

(Int Marit Health 2013; 64, 4: 207-214)

Key words: recreational boating, sub-aqua diving, fatalities

\section{INTRODUCTION}

Maritime occupations have been 2 of the most hazardous occupations in most European countries for a long time [1-6], while drowning is a leading cause of death from non-natural causes in many countries [7-10].

In recent years, there have been increases in recreational boating in many countries, [11-13] involving, for example, motor boats, yachts, canal barges, canoes and other personal watercraft. However, relatively little has been reported about the causes and rates of fatal accidents in these areas of maritime leisure activity in Europe.

The main objectives of this study were, firstly, to establish the causes and circumstances of all fatal accidents and drownings that occurred from recreational boating and sub-aqua diving inland or in waters around the United Kingdom (UK) during the recent 2 years, 2006 and 2007. Further objectives were to compare fatality rates according to the different types of recreational boating activity and sub-aqua diving, to identify causal patterns, and to discuss preventative measures to reduce the fatalities.

\section{MATERIALS AND METHODS}

This study included fatalities that occurred from recreational boating and sub-aqua diving in waters around the UK or inland during the 2-year period from January $1^{\text {st }}, 2006$ to December $31^{\text {st }}, 2007$. Additionally, the study

Dr Stephen E. Roberts, College of Medicine, Swansea University, Singleton Park, Swansea SA2 8PP, United Kingdom, tel: +44 (0) $1792513433 / 513426$

fax: +44 (0) 1792513 423, e-mail: stephen.e.roberts@swansea.ac.uk 
included fatalities in yachting that occurred in other seas. The study excluded all fatalities from commercial vessels such as merchant ships, commercial fishing vessels and other small work boats.

\section{INFORMATION SOURCES}

The official marine accident investigative authority in the UK, the Marine Accident Investigation Branch (MAIB) [14], is notified of and investigates fatal accidents that occur from British registered boats or among British nationals. The MAIB is also regularly notified of fatalities that arise through recreational water-related activities and sports around the UK. The first main study information source used in this paper were marine accident investigation files and reports by the MAIB.

In order to identify all other possible fatalities from recreational boating and sub-aqua diving inland or in waters around the UK, the study authors and the MAIB conducted extensive reviews and searches of additional information sources for fatalities that satisfied the study inclusion and exclusion criteria. These additional information sources included, firstly, databases from the Royal National Lifeboat Institution and the Maritime Coastguard Agency, namely the Sea Related Emergency database (SEAREM), which covers fatalities at sea and the Inland Related Emergency database (INREM), which covers water-related fatalities inland. INREM also includes information from the police, fire and ambulance service records.

Secondly, the information was obtained from the files held at the Registry of Shipping and Seamen, which registers fatalities at sea among British nationals or from British-registered boats. Thirdly, the data were obtained from The Royal Life Saving Society UK, which records drowning events collected from the police and coroners' records. Fourthly, the information was collected from the Royal Society for the Prevention of Accidents, which uses a press-cutting service to compile information on drownings in the UK. Fifthly, the data was obtained from the Association of Inland Navigation Authorities (AINA), which covers drownings on canal barges and in lakes. Next, the information was obtained from the British Sub-Aqua club, which covers fatalities in sub-aqua diving [15]. Finally, additional information was collected through Internet searches and searches of newspapers.

\section{POPULATIONS AT RISK}

The information on populations engaged in various recreational boating and sub-aqua diving activities were obtained from annual water sports and leisure participation surveys conducted by the British Marine Federation, the Maritime Coastguard Agency, the Royal National Lifeboat Institution and The Royal Yachting Association [11]. The populations at risk were defined, firstly, in terms of the num- ber of people that participated in these various maritime activities and, secondly, in terms of the number of events or occasions that the activities were participated in.

\section{CLASSIFICATION OF RECREATIONAL BOATS}

The recreational boating activities were classified using the following 11 categories, which were based on the annual water sports and leisure participation surveys [11], and through consultations with the MAIB: i) canal (or narrow) boats; ii) yachts; iii) small sailing boats; iv) canoes and kayaks; v) angling and other non-commercial fishing boats; vi) motor and power boats; vii) water ski craft; viii) kitesurfing craft; ix) jet ski and other personal watercraft; $\mathrm{x}$ ) rowing boats and $\mathrm{xi}$ ) other boats, which include houseboats and other miscellaneous boats and crafts. The categories water ski/kitesurfing/jet ski/ /other personal watercraft and, secondly, rowing/other boats were aggregated respectively in some analyses because of relatively small numbers of fatalities. Sub-aqua diving was considered separately as a $12^{\text {th }}$ category.

Fatal accident rates were based on the numbers of fatal accidents divided by the populations, and were expressed per million participants, per million events and per million resident general population. When establishing fatal accident rates, deaths from natural causes and confirmed suicides or homicides were excluded. Other methods of analysis included Geographical Information Systems mapping, bar charts and 95\% confidences for fatal accident rates.

\section{RESULTS}

During the study period, there were a total of 102 fatalities among people engaged in recreational boating and 28 in sub-aqua diving that were included in this study (Table 1).

\section{FATALITIES IN RECREATIONAL BOATING}

Of the 102 deaths in recreational boating, 4 were subsequently determined to have been due to natural causes, rather than accidents. A further 2 fatalities were determined to have been a suicide and a homicide respectively (Table 1 ). The other 96 fatalities were either confirmed accidents or were most likely the result of accidents. The underlying causes of death for 102 fatalities were: drowning or presumed drowning in 80 cases ( $78 \%$ ), asphyxiation by fumes (8), injuries or burns (7), acute myocardial infarction (4), and other causes (3).

The majority of 102 fatalities in recreational boating occurred through yachting, canoeing or kayaking and motor or power boating (Table 1). The most common causes of fatal accidents were pleasure boats and crafts capsizing or foundering, falls overboard and fires or explosions (Table 1).

Fatalities through capsize or foundering of boats and crafts were most common in canoes and kayaks ( $81 \%$ of all fatal accidents in canoes and kayaks), angling and fishing 


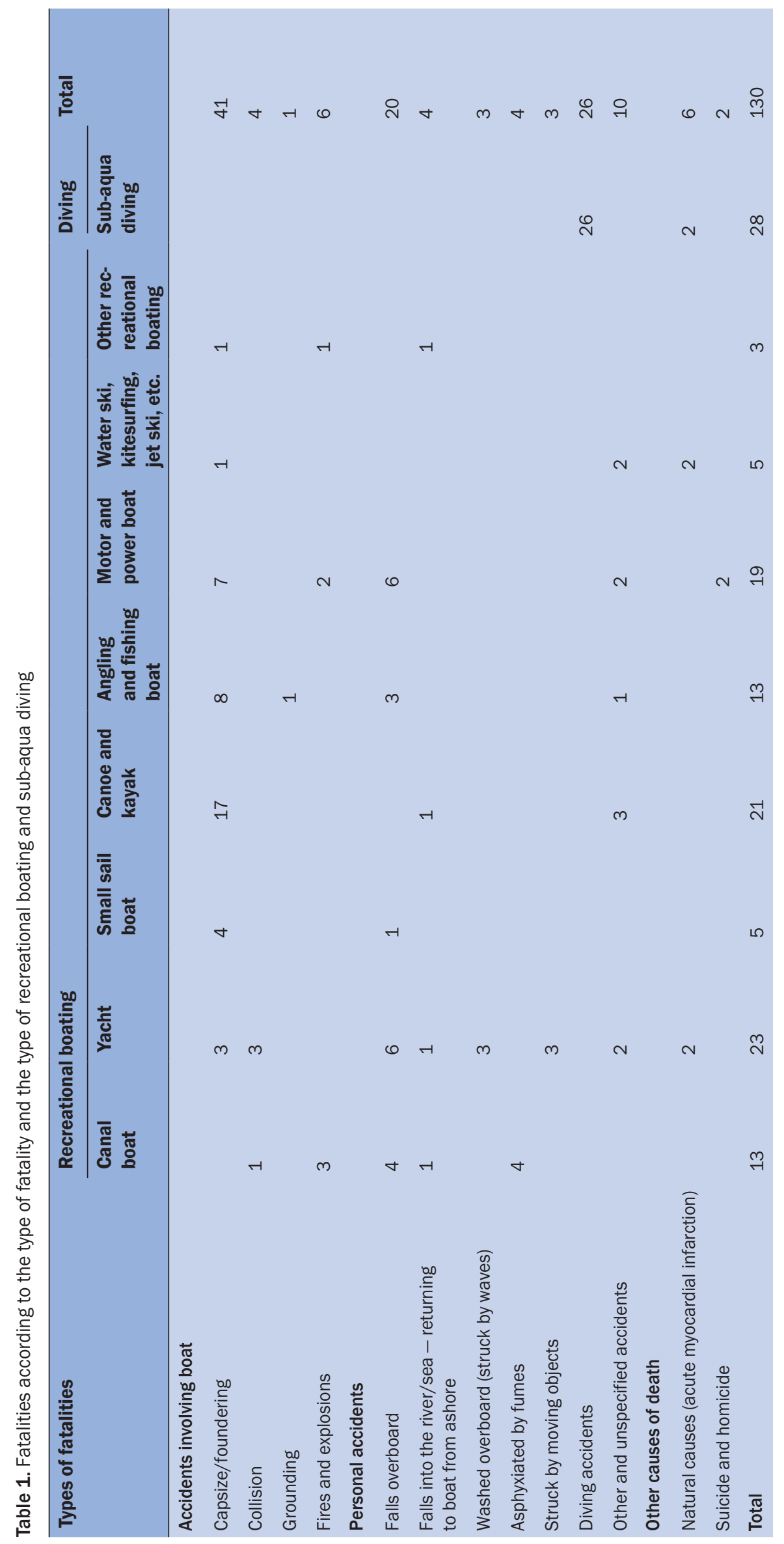




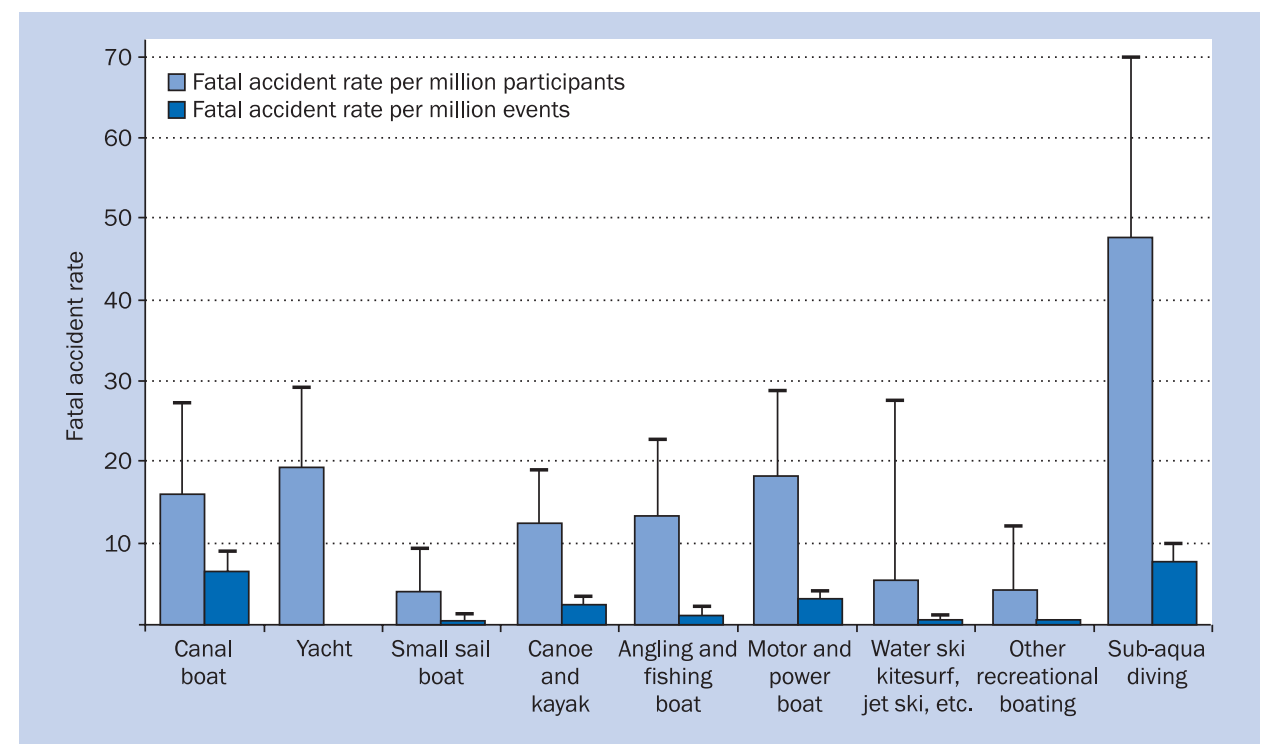

Figure 1. Fatal accident rates according to the type of recreational boating and sub-aqua diving. Notes: Vertical bars represent 95\% confidence intervals; the fatal accident rate per million events for yachting could not be obtained because of unavailability of information on the population at risk

boats (62\%) and motor and power boats (37\%). Fatal falls over board were most common in motor and power boats (32\% of all deaths in power or motor boats), canal boats $(31 \%)$ and yachts $(26 \%)$. Fatalities through fires or explosions were most common in canal boats $(23 \%)$.

The overall fatal accident rate for the 96 confirmed or probable accidents in recreational boating was 12.0 per million participants (95\% confidence interval [Cl] 9.7-14.7), 1.6 per million events $(95 \% \mathrm{Cl} 1.2-2.0)$, and 0.8 per million resident population $(95 \% \mathrm{Cl} 0.6-0.9)$. In terms of the number of people participating, the highest fatal accident rates in recreational boating (Fig. 1) were for motor and power boats (20.2 per million participants), yachts (19.3), and canal boats (16.0). In terms of number of events or occasions the boating activities were carried out, the highest fatal accident rates were for canal boats $(6.6$ per million events), followed by kitesurfing (3.3), motor and power boats (3.2), and canoes and kayaks (2.5). The number of events was not available for yachting.

\section{FATALITIES IN SUB-AQUA DIVING}

Of the 28 deaths in sub-aqua diving, 2 were caused by acute myocardial infarction, the other 26 were from diving accidents (Table 1). The underlying causes of death for the 26 accidents were decompression illness (10), drowning (9), asphyxiation through oxygen deficiency (6), and unknown cause (1). Only 2 of the 28 were lone divers, both died from acute myocardial infarction.

In terms of number of people participating, the fatal accident rate in sub-aqua diving (48.0 per million partici- pants) was significantly higher $(p<0.05)$ than in all types of recreational boating (Fig. 1). In terms of events, sub-aqua diving also had the highest fatal accident rate (7.6 per million events), although this was not significantly higher than for canal boating (6.6) or kitesurfing (3.3). The fatal accident rate in sub-aqua diving in the general resident population was 0.2 per million people.

\section{ALCOHOL CONSUMPTION}

Alcohol consumption was recorded as a causal factor in 24 (24\%) of the 102 fatalities in recreational boating (Fig. 2). It was most prevalent in canal boats ( 7 of 13 or $54 \%$ of fatalities in canal boats), followed by motor and power boats ( 6 of $19 ; 32 \%$ ), angling and fishing boats ( 4 of $13 ; 31 \%$ ) and canoes or kayaks (3 of $21 ; 14 \%$ ). None of the fatalities in sub-aqua diving were recorded as alcohol-related.

\section{MONTH OF THE YEAR}

Most of the fatalities occurred during the 6 months from April to September $(80 ; 64 \%)$, with a peak in fatalities during August (22 fatalities; Fig. 3). Fatalities in sub-aqua diving and motor and power boats occurred mainly during these 6 months ( 23 of 28 fatalities and 14 of 19 , respectively), while fatalities during the autumn and winter months were mainly confined to canal boats, yachts and canoes or kayaks.

\section{LOCATION OF THE FATALITIES}

Figure 4 shows that the geographical dispersion of the fatalities varies strongly according to the type of recreational boat. Fatalities from canoes and kayaks were most com- 


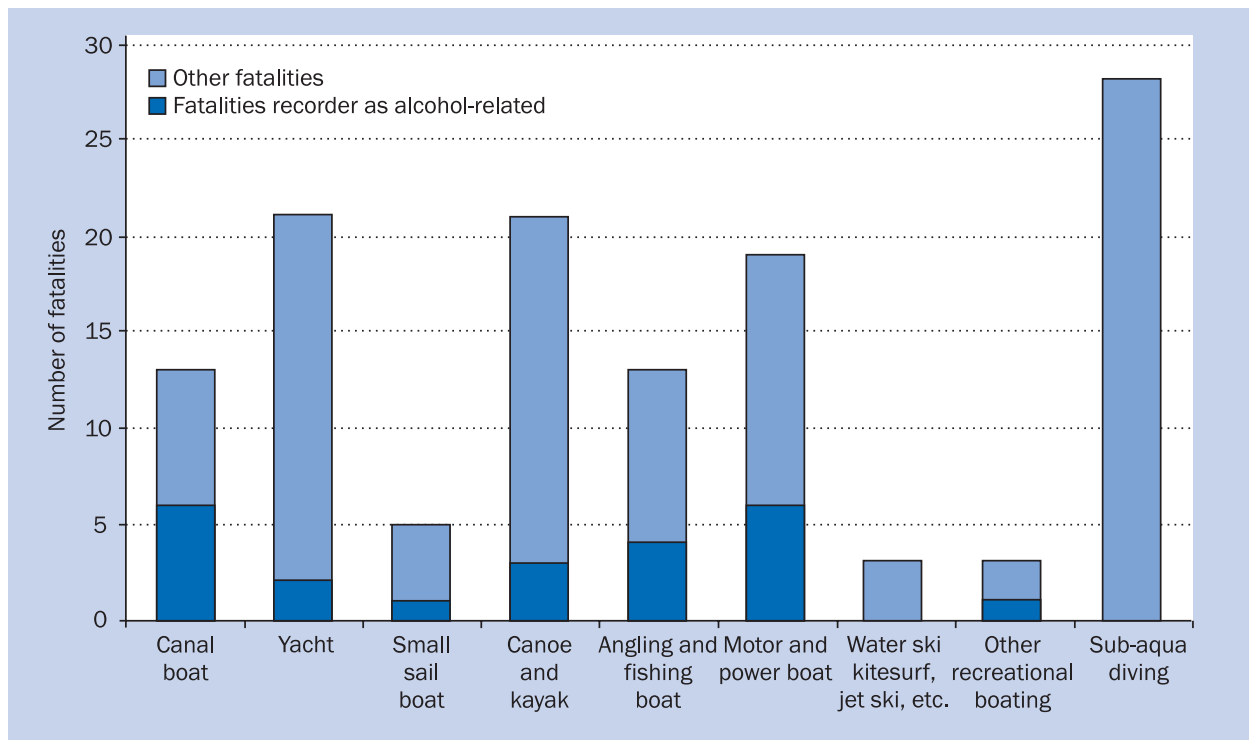

Figure 2. Fatalities reported as alcohol-related according to the type of recreational boating and sub-aqua diving

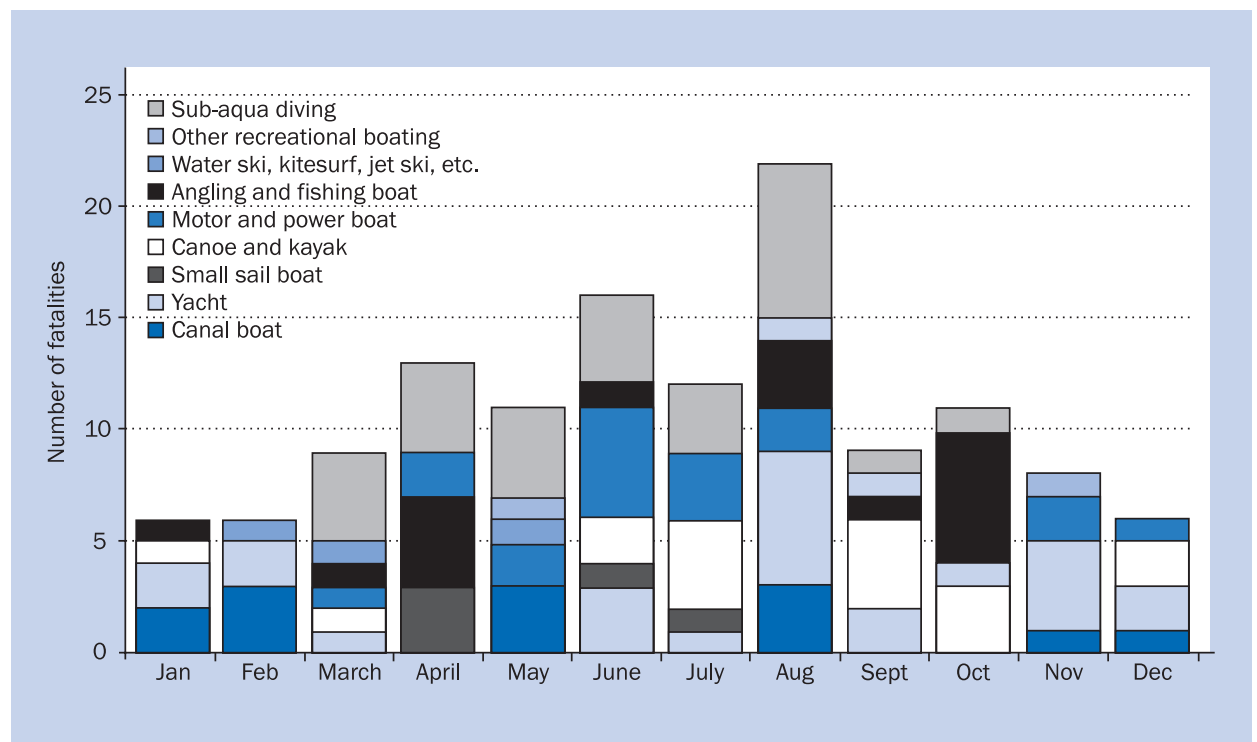

Figure 3. Fatalities according to month of the year and type of recreational boating and sub-aqua diving

mon in Scotland (lochs) and north west of England (Lake District), while most fatalities from yachts occurred in the English Channel.

\section{CAUSES AND CIRCUMSTANCES OF THE FATALITIES}

Of 13 fatalities from canal boats, 7 occurred during autumn or winter, all among people who were using the canal boats as residential homes. Six of the 7 were known to be alcohol-related, 3 after the deceased had returned from public houses ashore. Two were killed in galley fires, 2 fell into canals and 3 were asphyxiated by fumes, 2 of these from engine fumes when attempting to charge the canal boat battery. Two other people who were living in houseboats similarly died when falling into the river after drinking ashore and after a galley fire.

of 6 canal boat fatalities during spring and summer, 3 were also using boats as homes when they died through a galley fire, asphyxiation by stove fumes and a fall overboard. The others were using canal boats for holidays when they fell overboard (2) and were involved in a collision. The fatality rate from canal barges that were being used for holidays rather than as residential homes was relatively low (3.7 per million participants and 1.5 per million holidays). 


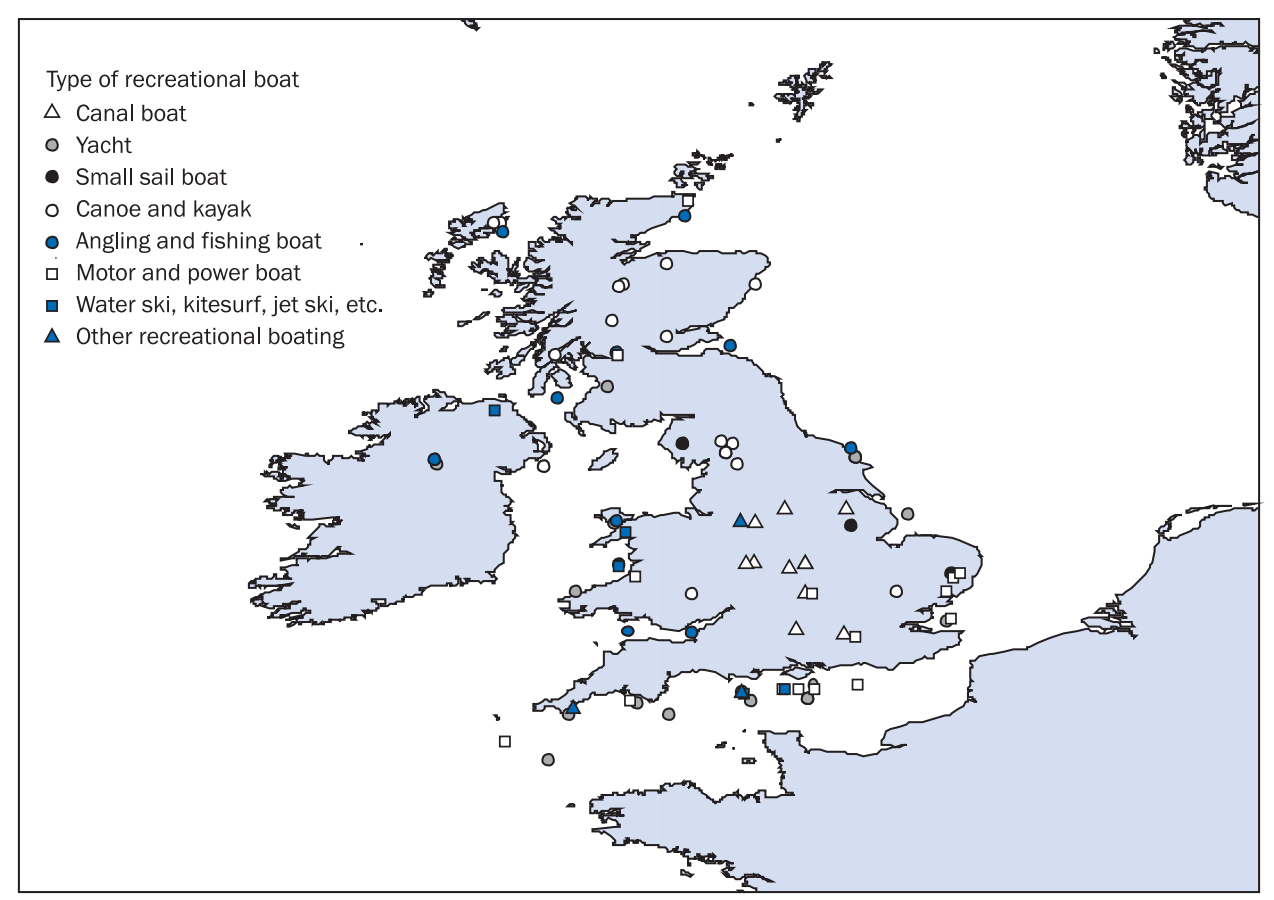

Figure 4. Locations of fatalities according to the type of recreational boating

Of 21 fatalities from canoes and kayaks, 10 of the deceased were aged 21 years or younger, most occurred inland (14) rather than in coastal waters, mainly in lakes, lochs and upstream (non-tidal) rivers. In most cases (17) the canoe or kayak capsized or overturned (Table 1). The main causal factors cited were inexperience or risk perception (10 cases), bad weather (7), alcohol consumption (3), and structural deficiencies (2).

In yachting, of 23 fatalities, all but 4 were caused by drowning or immersion, the others through injuries or myocardial infarction (2 each). The main causal factors were bad weather (11 cases), inexperience or perception of risk (7), no harnesses or personal flotation devices worn, navigational error and alcohol (3 each), and structural deficiencies in the boats (2).

of 19 fatalities in motor and power boating most were caused by capsize or falls overboard (Table 1), and the main causal factors cited were risk perception or inexperience (8), alcohol (6), structural defects (4), bad weather (3), homicide, suicide and physical illness (1 each). For angling and fishing fatalities, the main causes cited were adverse weather (7), perception of risk (6) including no personal flotation devices worn (5), structural defects and alcohol consumption (3 each), and navigational error (2).

\section{DISCUSSION}

This study was based on extensive reviews of fatal accident investigation files and other marine fatality information sources, as well as additional searches of other information sources. It is expected that almost all of the fatalities that occurred from recreational boating and sub-aqua diving during the study period would have been identified.

Limitations of the study include, firstly, that it was based on 2 years, 2006 and 2007. In 2006, the summer was mostly dry and sunny in the UK, while the latter part of 2007 experienced torrential rain with major flooding in many regions. The 2-year study period is therefore probably quite representative of the typical climate in which these boating fatalities occurred. Secondly, detailed findings of fatal accident investigations and other death inquiries were available for almost all of the fatalities in different sectors of recreational boating and pleasure craft except those in sub-aqua diving. Alcohol consumption was available as a reported causal factor in most, but not all fatalities, so that the analyses of the impact of alcohol on fatalities are subject to some under reporting.

The fatality rate in recreational boating of 0.8 per million population in this study compares with 2.0 per million in Australian recreational boating in 1998 [16], 2.4 per million in USA recreational boating from 2001 to 2010 [17], 4.0 in New Zealand from 2000 to 2006 [18], and 4.3 per million in Canada from 2006 to 2008 [19]. These population-based fatal accident rates are dependent to some extent on the degree to which the general populations in these countries participate in recreational boating and also on local water temperatures. Sometimes there are also variations across the studies in terms of defining fatal accidents and types of recreational boats and crafts included in the studies.

We have found that the causal patterns of the fatalities, as well as the fatality rates, varied very strongly according to 
the type of recreational boating. $24 \%$ of the fatalities in recreational boating were reported as alcohol-related. Although this would be an underestimate, it is similar to $18 \%$ recorded in New Zealand pleasure boating from 2000 to 2006 [18], $22 \%$ in US recreational boating from 2006 to 2010 [17], 25\% in Tasmanian boating from 1987 to 1999 [20], and 24\% reported in Polish small-scale fishing from 1960 to 1999 [21]. A study of Canadian recreational boating from 1991 to 2008, however, reported a much higher rate of alcohol-related fatalities (39\%), which increased to $46 \%$ when including cases of suspected, but not confirmed alcohol use [19]. A previous review has suggested that people with blood alcohol level of $>100 \mathrm{mg} / 100 \mathrm{~mL}$ have about a 10 times increased risk of death in recreational boating when compared with people who have not been drinking [22]. Although under-reported in our study, fatalities that were alcohol-related were most prevalent in canal boats and houseboats, followed by motor or power boats and angling or other non-commercial fishing boats.

We have found that sub-aqua diving had a much higher fatality rate (48 per million participants) than recreational boating (12 per million). This is lower than 164 per million participants reported for North Carolina diving, USA, from 2000 to 2006 [23], but is comparable with 30 to 90 per million participants across the entire USA [24], and higher than 29 per million inland in Leicester from 1992 to 1996 [25]. Our fatality rate of 7.6 per million dives is similar to 5.7 per million in Australia from 1972 to 2006 [26], and 7.0 in the USA from 2000 to 2006 [27]. As in other studies [27-29], deaths in sub-aqua diving were caused mainly by drowning or decompression illness. Prevention should be aimed primarily at suitable training and practice in advance, adherence to safety guidelines, medical fitness and avoiding lone diving [30-32].

The study found a surprisingly high incidence of fatal accidents from canal boats and barges. However, a minority of these cases involved people who were using the canal boats for holidays. Most of the fatalities arose when the canal boats were being used instead as homes and most of these deaths were alcohol-related, most occurred during the winter months and usually involved fires in galleys, falls into canals after drinking ashore and asphyxiation by fumes from galley stoves or engines. Two other people died in similar circumstances from houseboats. Fatalities arising through fires on residential boats would often be prevented through the installation and maintenance of smoke alarms and fire extinguishers $[19,33$, 34]. Prevention should also be aimed primarily at awareness of the potential hazards of drinking heavily when living on boats in canals and rivers. After excluding fatalities among the people who were using canal boats as residences, the fatality rate for the people who were using boats for summer holidays was low.

Our fatal accident rate for canoes of 12 per million participants compares with 8 per million in the USA in 2009 [35]. The fatalities in canoes and kayaks occurred mainly inland rather than in coastal waters, often among children and young adults and were often caused by inexperience and risk perception rather than by other factors, such as bad weather conditions. Prevention should be aimed towards adequate prior training and supervision of novices who use canoes. Quite a high proportion of fatalities in yachting was also attributable to inexperience or perception of risk, which suggests that prevention in yachting should be targeted at training and gaining experience that involves supervision.

One of the main contributory causes of fatalities in recreational boating was a lack of life jackets or personal flotation devices worn. This was most apparent among fatalities from angling and other non-commercial fishing vessels. The use of life jackets or personal flotation devices has been shown previously to greatly improve survival prospects following water craft accidents [18, 36, 37], and is often the most important preventative measure in recreational boating.

\section{CONCLUSIONS}

1. The fatal accident rates in recreational boating and sub-aqua diving were 12.0 and 48.0 per million participants respectively. In recreational boating, fatal accident rates were highest for motor and power boats (20.2), yachts (19.3) and canal boats (16.0).

2. Fatalities that were alcohol-related were most frequent in canal boats and occurred largely during the autumn and winter months rather than during summer holidays, involving people who were residing on the boats, and often resulted from galley fires and falls overboard.

3. The causal patterns of fatalities varied strongly according to the type of recreational boat.

4. Measures to prevent fatalities should include raising awareness of hazards, adequate training in diving, yachting and canoeing, etc., smoke alarms and fire extinguishers on residential boats, and more widespread use of personal flotation devices in recreational boating.

\section{ACKNOWLEDGEMENTS}

The authors are grateful to Cathy Pennock and the Marine Investigation Branch for providing fatal accident investigation files, for searches for fatalities included in this study, and for advice with the classification of recreational boating in this study. The authors are also grateful to the Registry of Shipping and Seamen for providing access to their death inquiry files, all other organisations that assisted with data provision for this study and also Ashley Akbari for Geographical Information Systems mapping.

\section{REFERENCES}

1. Royal Commission on Loss of Life at Sea. First report of the Royal Commission on Loss of Life at Sea with minutes of evidence. Eyre and Spottiswoode, London 1885. 
2. Vuksanovic $P$, Goethe H. Diseases and accidents among seamen an international comparison of distribution of diagnoses. Bull Inst Marit Trop Med Gdynia 1982; 33: 13-33.

3. Jaremin B, Kotulak E, Starnawska M, Tomaszunas S. Causes and circumstances of deaths of Polish seafarers during sea voyages. J Travel Med 1996; 3: 91-95.

4. Hansen HL. Surveillance of deaths on board Danish merchant ships, 1986-1993: implications for prevention. Occup Environ Med 1996; 53: $269-275$.

5. Nielsen D, Roberts S. Fatalities among the world's merchant seafarers (1990-1994). Marine Policy 1999; 23: 71-80.

6. Jaremin B. [Deceases of the Polish seamen and fishermen at maritime work-site in the years 1960-1999: analysis of phenomenon and impact of work environment, with particular reference to medical certification and possibilities of prevention]. Ann Academiae Med Gedanensis 2005; supplement 1.

7. Lunetta P, Penttilä A, Sarna S. Water traffic accidents, drowning and alcohol in Finland, 1969-1995. Int J Epidemiol 1998; 27: 1038-1043.

8. Skog OJ. Alcohol consumption and fatal accidents in Canada, 1950-1998. Addiction 2003; 98: 883-893.

9. Strayer HD, Lucas DL, Hull-Jilly DC, Lincoln JM. Drowning in Alaska: progress and persistent problems. Int J Circumpolar Health 2010; 69: 253-264.

10. AhIm K, Saveman BI, Björnstig U. Drowning deaths in Sweden with emphasis on the presence of alcohol and drugs: a retrospective study, 1992-2009. BMC Public Health 2013; 13: 216.

11. British Marine Federation, Maritime Coastguard Agency, Royal National Lifeboat Institution and The Royal Yachting Association. Watersports and Leisure Participation Surveys [annual surveys 2006 and 2007]. Southampton: Maritime and Coastguard Agency, 2007-2008.

12. National Marine Manufacturers Association (NMMA). Recreational Boating is $\$ 121$ Billion Economic Driver for U.S. New data show 88 million Americans expected to take to U.S. waterways this summer (www.nmma.org/news.aspx?id=18375; date last accessed November $21^{\text {st }}$ 2013).

13. Melbourne Water. Understanding the Western Port Environment: a summary of current knowledge and priorities for future research. Melbourne, Australia: Melbourne Water, 2011

14. Marine Accident Investigation Branch (http://www.maib.gov.uk/ home/index.cfm; date last accessed November $21^{\text {st }} 2013$ ).

15. British Sub-Aqua Club. Diving Incidents Report [annual returns, 2006, 2007]. British Sub-Aqua Club, London 2007-2008.

16. O'Connor P. Assessment of fatal and non-fatal injury due to boating in Australia. Adelaide: Flinders University of South Australia, Adelaide, 2001.

17. United States Coast Guard. Recreational Boating Statistics, 2010. Commandant Publication P16754.24. United States Coast Guard, Washington DC, USA 2011.

18. Maritime New Zealand. Boating Safety Strategy: 2007 Review of the New Zealand Pleasure Boat Safety Strategy. Maritime New Zealand, Wellington, New Zealand 2008.
19. Transport Canada and the Canadian Red Cross. Boating Immersion and Trauma deaths in Canada: 18 years of research. Transport Canada and The Canadian Red Cross Society, Ottawa, Canada 2011.

20. Marine and Safety Tasmania. Recreational Boating Safety Review. Marine and Safety Tasmania, Hobart, Tasmania 2000.

21. Jaremin B, Kotulak E. Mortality in the Polish small-scale fishing industry. Occup Med (Lond) 2004; 54: 258-260.

22. Driscoll TR, Harrison JA, Steenkamp M. Review of the role of alcohol in drowning associated with recreational aquatic activity. Inj Prev 2004; 10: 107-113.

23. Denoble PJ, Pollock NW, Vaithiyanathan P, Caruso JL, Dovenbarger JA, Vann RD. Scuba injury death rate among insured DAN members. Diving Hyperb Med 2008; 38: 182-188.

24. Morgan WP. Anxiety and panic in recreational scuba divers. Sports Med 1995; 20: 398-421.

25. Hart AJ, White SA, Conboy PJ, Bodiwala G, Quinton D. Open water scuba diving accidents at Leicester: five years' experience. J Accid Emerg Med 1999; 16: 198-200.

26. Lippmann J. Review of scuba diving fatalities and decompression illness in Australia. Diving Hyperb Med 2008; 38: 71-78.

27. Denoble PJ, Caruso JL, Dear Gde L, Pieper CF, Vann RD. Common causes of open-circuit recreational diving fatalities. Undersea Hyperb Med 2008; 35: 393-406.

28. Definis-Gojanović M, Bresković T, Sutlović D, Petri N. Divers' deaths in Split-Dalmatian County, Croatia (cases study, 1994-2004). Int Marit Health 2007; 58: 139-48.

29. Divers Alert Network America. Annual diving report: 2007 Ed. Divers Alert Network America, Durham, North Carolina, USA 2007.

30. Maritime and Coastguard Agency. Discover Sea Diving Safely. Southampton: Maritime and Coastguard Agency, 2004.

31. British Sub-Aqua Club. Safe Diving: Your Guide to the Safe Practices of Sports Diving as Recommended by the British Sub-Aqua Club. British Sub-Aqua Club, London 2011.

32. Kot J, Sićko Z, Michałkiewicz M, Lizak E, Góralczyk P. Recompression treatment for decompression illness: 5-year report (2003-2007) from National Centre for Hyperbaric Medicine in Poland. Int Marit Health 2008; 59: 69-80.

33. Marine Accident Investigation Branch. Report on the investigation of the fire on board the canal boat Lindy Lou at Lyme View Marina, Adlington resulting in 1 fatality. Marine Accident Investigation Branch, Southampton 2007.

34. Marine Accident Investigation Branch. Report on the investigation of the fire and subsequent sinking of Lady Candida off Corsica, 28 July 2007. Marine Accident Investigation Branch, Southampton 2007.

35. Franklin RC, Leggat PA. The epidemiology of injury in canoeing, kayaking and rafting. Med Sport Sci 2012; 58: 98-111.

36. Cummings P, Mueller BA, Quan L. Association between wearing a personal floatation device and death by drowning among recreational boaters: a matched cohort analysis of United States Coast Guard data. Inj Prev 2011; 17: 156-159.

37. Browne ML, Lewis-Michl EL, Stark AD. Watercraft-related drownings among New York State residents, 1988-1994. Public Health Rep 2003; 118: 459-463. 